\title{
Cytoreductive Surgery for Intestinal Cancer Patients Metastatic to Ovaries Presenting as Primary Ovarian Cancer
}

\author{
Zafer ARIK ${ }^{1}$, Murat OZ ${ }^{1}$, Omer DIZDAR ${ }^{2}$, M. Emre YILDIRIM'1, \\ Emre OZGU'1, S. Gokay TERZIOGLU ${ }^{3}$, Tayfun GUNGOR ${ }^{1}$ \\ ${ }^{1}$ Zekai Tahir Burak Women's Health Training and Research Hospital, Department of Medical Oncology
${ }^{2}$ Hacettepe University, Cancer Institute, Department of Medical Oncology
${ }^{3}$ Ankara Numune Training and Research Hospital, Department of General Surgery, Ankara, TURKEY
}

ABSTRACT

Colorectal cancer accounts for one third of non-genital tumors metastasize to the ovaries. We aimed to investigate the role of cytoreductive surgery in colon and small intestinal cancer patients with adnexal metastases, which were operated as primary epithelial ovarian cancer. This analysis included 26 patients with adnexal metastasis from colon and distal ileum, patients presented as primary ovarian cancer cases and were operated upon in Zekai Tahir Burak Women's Health Hospital, Gynecologic Oncology Unit between 2008 and 2014. Patients with history of intestinal cancers were not included in the study. The median age of patients was 54 (range= 26-77). Among all patients, $63 \%$ were premenopausal and $37 \%$ were postmenopausal. Most common presenting symptom was abdominal distention (80\%). Optimal cytoreduction was performed in 21 patients. Right hemicolon was the primary site of tumor in 8 patients, while recto-sigmoid and appendiceal tumors were present in 7 and 7 patients, respectively. Isolated ovarian metastases were found in 6 patients, the remaining 20 patients had peritoneal carcinomatosis. Median follow-up was 25 months (ranging 3-59). In total, 11 patients died, of them, two patients had isolated ovarian metastasis, while the remaining nine patients had peritoneal carcinomatosis. Estimated median overall survival was 36.8 months ( $95 \% \mathrm{Cl}=28.6-45.1$ months). Median overall survival of patients who underwent cytoreductive surgery was not reached (36.8+ months), compared with 18.3 (95\% Cl= 0.0-46.4) months for patients with suboptimal cytoreductive surgery $(\mathrm{p}=0.008)$. This retrospective study showed that cytoreductive surgery might have beneficial effect in selected patients with intestinal cancer metastatic to the adnexal.

Keywords: Cytoreductive surgery, Nongenital cancer, Ovary, Colon cancer

ÖZET

Primer Over Kanseri Olarak Prezente Olan Over Metastatik İntestinal Kanser Hastalarında Sitoredüktif Cerrahi

Kolorektal kanser, overe metastaz yapan non-genital kanserlerinin 1/3'ünü oluşturur. Bu çalışmamızda primeri kolon veya ince bağırsak kanseri olup adnekse metastazı olan hastalarda sitoredüktif cerrahinin rolü incelenmiştir. 2008-2014 yılları arasında Zekai Tahir Burak Kadın Sağlığı Eğitim ve Araştırma Hastanesi jinekoloji kliniğinde adneksiyel kitle ön tanısıyla opere edilen primeri kolon veya ince bağırsak olan hastaların verileri retrospektif olarak incelenmiştir. Cerrahi öncesi intestinal kanser öyküsü olan hastalar çalışmaya alınmamıştır. Hastaların ortanca yașı 54 (26-77) bulundu. Premenopozal olanlar hastaların \%63'ü iken postmenopozal olanlar \%37'di. En sık başvuru şikayeti karın şişkinliğiydi (\%80). Optimal sitoredüksiyon 21 hastada yapılabildi. Sağ kolon kaynaklı olan 8 hasta, rektosigmoid kaynaklı 7 hasta, appendiks kaynaklı 7 hasta saptandı. Patolojisi müsinöz adenokarsinom olan 12 hasta saptandı. İzole over metastazı 6 hastada saptanırken peritoneal karsinomatozis 20 hastada saptandı. Ortanca takip süresi 25 ay (3-59) bulundu. Hastaların 11'inde ölüm gerçekleşti. İzole over metastazı olan hastalardan 2'sinde ölüm saptandı. Peritoneal karsinomatozisli 20 hastadan 9'unda ölüm gelişti. Ortanca genel sağkalım 36.8 ay [\%95 GA: 28.6-45,1] olarak saptandı. Optimal sitoredüksiyon yapılan hastalarda ortanca sağkalıma ulaşılamadı (ortalama 36,8 ay+). Suboptimal sitoredüksiyon yapılanlarda ortanca sağkalım anlamlı olarak daha düşük saptandı (ortanca sağkalım 18.3 ay, [\%95 GA: 0.0-46.4] p= 0.008) Bu retrospektif çalışmada sitoredüktif cerrahinin, adnekslere metastaz yapmış olan intestinal kanserli seçilmiş vakalarda yararlı olabileceği gösterilmiştir.

Anahtar Kelimeler: Sitoredüktif cerrahi, Nongenital cancer, Over, Kolon kanser 


\section{INTRODUCTION}

It is estimated that about $10-30 \%$ of all ovarian malignancies are metastatic from genital and nongenital tumors. The most common origins of nongenital tumors are stomach, colorectal and breast. Colorectal cancer accounts one third of nongenital tumors metastatic to ovaries. ${ }^{1-4}$

Among the patients with peritoneal carcinomatosis (PC) of epithelial ovarian cancer origin, cytoreductive surgery is the standard of care. An attempt at maximal removal of tumor burden yields better survival rates in ovarian cancer. ${ }^{5,6}$

Colorectal cancer is the third most common cause of cancer-related deaths in female in the United States. ${ }^{7}$ About $7 \%$ of patients with colorectal cancer will encounter PC in initial surgery, $4 \%$ to $19 \%$ of patients during follow up after curative surgery, and in up to $44 \%$ of patients with recurrent colorectal cancer who require surgery will present with PC. ${ }^{8}$ Although chemotherapy has long been the mainstay of therapy in PC colorectal cancer, fluorouracil and palliative surgery yielded an overall survival of 5.2 to 7 months with PC colon cancer in fluorouracil-only era. ${ }^{9,10}$ During the past decade, despite the introduction of new modern cytotoxic chemotherapy and biological targeted therapies, median survival of colon cancer with PC is about 12.7 months. ${ }^{11}$

Researchers have explored the possible role of cytoreductive surgery in colon cancer with PC to improve survival. Cytoreductive surgery, and hyperthermic intraperitoneal chemotherapy (HIPEC) has demonstrated improved survival in several studies in colon cancer with PC. ${ }^{3,12-17}$ Despite these studies, the National Comprehensive Cancer Network suggests this approach as to be investigational and does not recommend outside of a clinical trial. ${ }^{18}$

This study aims to evaluate the role of cytoreductive surgery in colon and small intestine cancer patients with adnexal metastasis, which were operated as primary ovarian cancer.

\section{PATIENTS AND METHODS}

This retrospective cohort study included 26 patients with metastases to the adnexa from colon and distal ileum, which were operated as primary epithelial ovarian cancer in Zekai Tahir Burak
Women's Health Hospital, Department of Gynecologic Oncology between January 2008 and December 2014. Patients with history of intestinal cancers were not included in the study. All patients were operated with preoperative diagnosis of suspicious adnexal mass and cytoreductive surgery was performed after confirming malignant epithelial carcinoma with intraoperative frozen section. Cytoreductive surgery was consisting of total abdominal hysterectomy and bilateral salpingo-oophorectomy, omentectomy, and bilateral pelvic and paraaortic lymphadenectomy. In addition, colon resection or segmental small intestine resections were performed in optimally debulked patients according to primary site of origin. In terms of the type of surgery; surgical cytoreduction was considered optimal if the largest residual tumor volume was less than $1 \mathrm{~cm}$ in diameter. We compared optimal cytoreduced patients with sub-optimal cytoreduced ones in regards of overall survival.

Demographic characteristics of the patients and clinical data including age, menopausal status, main symptom, surgical treatment procedure, primary site of origin, and pathology reports were collected from the medical charts and computerized database of the Gynecologic Oncology Department. Overall survival was designated as the time from diagnosis to death or last known status. The study was approved by the Zekai Tahir Burak Women's Health Hospital Ethics Committee.

\section{Statistical Analysis}

Statistical analyses were performed by using SPSS for Windows version 18.0 (SPSS, Chicago, IL). The log-rank test was used to examine the statistical significance of the differences observed between the groups. Kaplan-Meier survival analysis was carried out for overall survival. Two-sided $\mathrm{P}$ values of $<0.05$ were considered statistically significant.

\section{RESULTS}

Twenty-six patients were included in this study. Majority of the patients had colon cancer ( $n=17$ ), seven patients had appendiceal cancer, and the remaining two patients had ileal cancer. The baseline demographic and clinico-pathologic characteristics of the patients were described in Table 1. 
The median age of the patients was 54 (ranging 2677). Among all patients, $63 \%$ were premenopausal and $37 \%$ were postmenopausal. Most common presenting symptom was abdominal distention for $21(80 \%)$ patients. Preoperative elevated CEA levels $(>5 \mathrm{ng} / \mathrm{ml})$ were found in $18(69 \%)$ of patients. Serum CA125/CEA ratio was $<25$ for $18(69 \%)$ patients. In all operations, there was collaboration between general surgeons and gynecological oncologists. Optimal cytoreduction was performed in 21 patients. All patients with isolated ovarian metastases were optimally debulked. In-hospital mortality was observed in none of the patients after cytoreductive surgery.

Twelve of pathology reports were mucinous adenocarcinoma. Right hemicolon was the primary site of the tumor for 8 patients, while rectosigmoid and appendiceal primaries were found in 7 and 7 patients, respectively. Isolated ovarian metastases were found in 6 patients, the remaining 20 patients had diffuse PC. Synchronous liver metastases were found in two patients, and one patient had spleen metastasis. Bilateral involvement of ovaries was found in $20(77 \%)$ patients and while, unilateral ovarian involvement was found in $6(23 \%)$ patients. Median number of dissected lymph nodes was 49 (range 1-131). Lymph node metastasis was found in $14(54 \%)$ patients.

Median follow-up was 25 months (range= 3.0-59.1 months). Eleven patients died at the end of follow up. Only two of the patients with isolated ovarian metastases died. The remaining 9 exitus had peritoneal carcinomatosis. Estimated median overall survival was 36.8 months (95\% CI: 28.6-45.1 months) for all cohort (Figure 1). One year overall survival was $85 \%$, 2-year overall survival was $71 \%$, and 3 -year overall survival was $52 \%$.

Estimated overall survival of patients with isolated ovarian metastases was not different from patients with diffuse peritoneal carcinomatosis $(35.5$ months [95\% CI: 3.1-67.9 months] vs. 36.8 months [95\% CI: 18.9-54.8 months], $\mathrm{p}=0.76$ ), respectively.

Seven patients with colorectal primary $(n=17)$ and 4 patients with appendiceal and ileal primaries $(n=$ 9) died in follow up. The estimated median survival of the colorectal cancer patients was 36.8 months and 31.8 months in those who had appendix and distal ileum as primary tumor origin $(\mathrm{p}=0.9)$.

\begin{tabular}{|ll|}
\hline Table 1. Baseline clinico-pathological characteristics of pa- \\
tients with intestinal cancers metastatic to adnexa
\end{tabular}

Optimal cytoreduction was associated with significantly longer overall survival. Median overall survival of patients who underwent optimal cytoreductive surgery was not reached $(36.8+$ months $)$, 


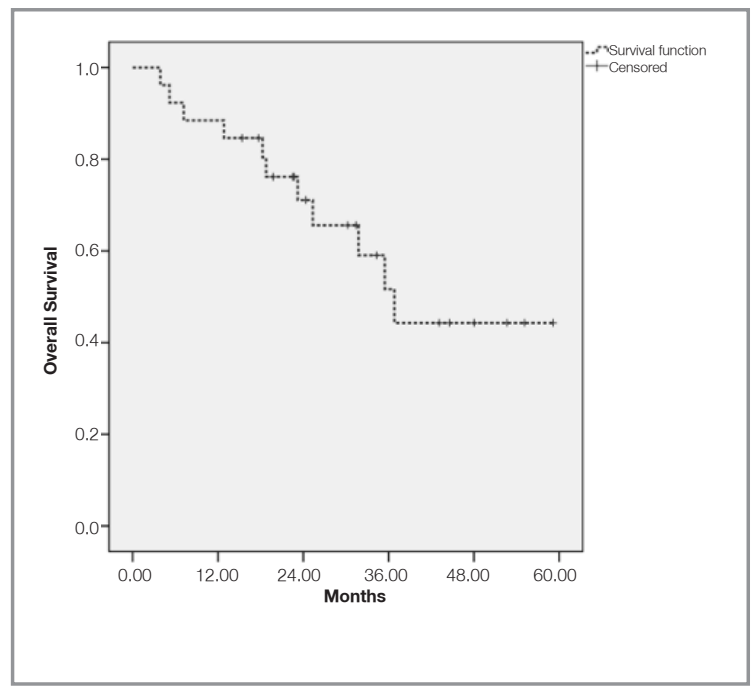

Figure 1. Analysis of overall survival of intestinal cancer patients with adnexal metastases, which were operated as primary ovarian cancer

compared with 18.3 (95\% CI: 0.0-46.4) months for patients with suboptimal cytoreductive surgery $(\mathrm{p}=$ 0.008) (Figure 2).

All patients were consulted postoperatively to medical oncology, which had expertise in intestinal cancers. Multi-agent regimens were used according to pathology reports and performance status of patients. Only one patient did not take chemotherapy because of poor performance status and died 3 months after the operation.

\section{DISCUSSION}

In the present study, we demonstrated an estimated median overall survival of 36.8 months for patients, which were undergone cytoreductive surgery without hyperthermic intraperitoneal chemotherapy (HIPEC) for ovarian metastases from intestinal origin. Because of reimbursement issues, our clinic does not systematically perform HIPEC. Our longterm survival was better than clinical trials, which used only cytotoxic chemotherapy and palliative surgery. In one of the largest published report to date; the median overall survival of patients with peritoneal carcinomatosis colorectal cancer was only 12.7 months with cytotoxic chemotherapy. ${ }^{11}$ Our better survival might be due to potential role of cytoreductive surgery or selection bias of patients, which were amenable to cytoreductive procedures, and also with better performance status.

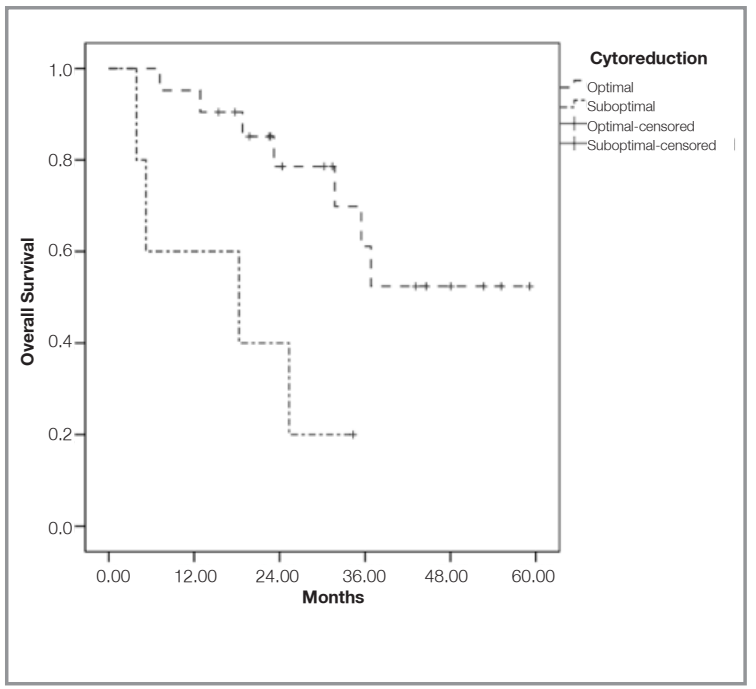

Figure 2. Analysis of overall survival of optimal debulked and suboptimal debulked patients with intestinal cancer metastatic to adnexa

Ovary is one of the most common sites of metastases from non-genital organs. The distinction between primary ovarian cancer from metastatic tumors may be difficult especially in which the primary site is gastrointestinal system despite the use of intraoperative frozen section evaluation. In such cases, many gynecologic oncologists perform cytoreductive surgery. ${ }^{19,20}$ Ovarian metastases occurs in $3 \%$ of patients with colorectal cancer. ${ }^{21} \mathrm{Com}$ plete resection of synchronous ovarian metastases from colorectal cancer is associated with improved survival outcome with an overall survival of $43.8 \%$ at 5 years. ${ }^{22}$

Several studies have focused on surgical efforts to improve survival in colorectal cancers with PC and appendiceal cancers. In these studies, cytoreduction followed by HIPEC demonstrated survival benefit significantly in colorectal cancers with PC. ${ }^{12,15,23,24}$ Goere et all demonstrated cure rate of $16 \%$ after complete cytoreductive surgery and intraperitoneal chemotherapy that is close to that obtained after resection of colorectal liver metastases. ${ }^{25}$ However, following this procedure, patients encountered more morbidity and mortality. Verhaal et all reported $8 \%$ mortality due to treatment complication and $65 \%$ of patients had grade 3,4 , or 5 toxicity. ${ }^{26}$ Unfortunately, debates exist about this complicated procedure. No accepted standard of care for the use of these modalities has been developed in guide- 
lines. ${ }^{18}$ A series of additional studies designed to assess the potential role of cytoreductive surgery with or without HIPEC are ongoing. ${ }^{27,28}$

In our study, isolated ovarian metastatic patients had a similar overall survival to these diffuse peritoneal carcinomatosis patients. This data is not consistent with literature in which isolated ovarian metastatic patients had a better overall survival. ${ }^{29,30}$ McCormic et all reported patients with isolated ovarian metastases had a median overall survival of 61 months compared to 17 months for women with disseminated disease. ${ }^{30}$ The low number of patients $(n=6)$ with isolated ovarian metastases in our study might have contributed to this similar overall survival. However, in a recently published study, researchers demonstrated that patients with ovarian metastases of colorectal or appendix origin who underwent cytoreductive surgery and HIPEC had similar outcome to patients with PC. ${ }^{31}$

In our study, we have shown cytoreduced colorectal or appendix origin was not different in terms of overall survival. The estimated median survival of the colorectal cancer patients was 36.8 months and 31.8 months in those who had appendix and distal ileum as primary tumor origin. Our findings were supported by Kuijpers, et all. In their study, appendix origin was not an independent predictor for survival in intestinal cancer patients. ${ }^{31}$

In the literature, optimal cytoreduction achieved significant survival benefit better than suboptimally debulked PC colorectal cancer patients. ${ }^{3,15,32}$ Glehen et all reported that the median survival of the completely cytoreduced patients was 32.9 months, while the median survival in the suboptimally cytoreduced was 8.1 to 12.5 months according to residual disease $(\mathrm{p}<0.001) .{ }^{32}$ In our study, we have shown that overall survival of patients with ovarian and peritoneal metastases undergoing optimal cytoreductive surgery was significantly better from patients undergoing suboptimal cytoreduction. Among patients with optimally cytoreduced, the estimated median overall survival was not reached ([36.8+ months] vs. 18.3 months for suboptimally cytoreduced patients $[\mathrm{p}=0.008])$. This survival benefit was consistent with those published reports in the literature. ${ }^{3,14,30,32}$

Retrospective design, missing data, and selection bias of patients, which were amenable to cytore- ductive procedures, are the limitations of our present study. And, the relatively low number of the study population and heterogeneous patients are another limitations of our study.

In conclusion, we have found that cytoreductive surgery may have beneficial effect in selected patients with intestinal cancer metastatic to the adnexal. Further prospective clinical trials such as ICARUS (NCT 01815359) will enlighten the best treatment option for patients with peritoneal carcinomatosis intestinal cancers.

\section{REFERENCES}

1. Mir O, Berveiller $P$, Veyrie $N$. The commonest primary sites for metastatic disease to the ovaries. J Surg Oncol 96: 639-640, 2007.

2. Yada-Hashimoto N, Yamamoto T, Kamiura S, et al. Metastatic ovarian tumors: a review of 64 cases. Gynecol Oncol 89: 314-317, 2003.

3. Ayhan A, Guvenal T, Salman MC, et al. The role of cytoreductive surgery in nongenital cancers metastatic to the ovaries. Gynecol Oncol 98: 235-241, 2005.

4. Turan T, Aykan B, Koc S, et al. Analysis of metastatic ovarian tumors from extragenital primary sites. Tumori 92: 491-5, 2006.

5. Bristow RE, Tomacruz RS, Armstrong DK, et al. Survival effect of maximal cytoreductive surgery for advanced ovarian carcinoma during the platinum era: a meta-analysis. J Clin Oncol 20: 1248-1259, 2002.

6. Eisenhauer EL, Abu-Rustum NR, Sonoda Y, et al. The addition of extensive upper abdominal surgery to achieve optimal cytoreduction improves survival in patients with stages IIICIV epithelial ovarian cancer. Gynecol Oncol 103: 1083-1090, 2006.

7. Siegel RL, Miller KD, Jemal A. Cancer statistics, 2015. CA Cancer J Clin 65: 5-29, 2015.

8. Koppe MJ, Boerman OC, Oyen WJ, Bleichrodt RP. Peritoneal carcinomatosis of colorectal origin: incidence and current treatment strategies. Ann Surg 243: 212-22, 2006.

9. Jayne DG, Fook S, Loi C, Seow-Choen F. Peritoneal carcinomatosis from colorectal cancer. Br J Surg 89: 1545-50, 2002.

10. Sadeghi B, Arvieux C, Glehen O, et al. Peritoneal carcinomatosis from non-gynecologic malignancies: results of the EVOCAPE 1 multicentric prospective study. Cancer 88: 358-363, 2000.

11. Franko J, Shi Q, Goldman CD, et al. Treatment of colorectal peritoneal carcinomatosis with systemic chemotherapy: a pooled analysis of north central cancer treatment group phase III trials N9741 and N9841. J Clin Oncol 30: 263-267, 2012. 
12. Sugarbaker PH. Peritonectomy procedures. Ann Surg 221: 29-42, 1995.

13. Elias D, Gilly F, Boutitie F, et al. Peritoneal colorectal carcinomatosis treated with surgery and perioperative intraperitoneal chemotherapy: retrospective analysis of 523 patients from a multicentric French study. J Clin Oncol 28: 63-68, 2010.

14. Glehen O, Kwiatkowski F, Sugarbaker PH, et al. Cytoreductive surgery combined with perioperative intraperitoneal chemotherapy for the management of peritoneal carcinomatosis from colorectal cancer: a multi-institutional study. J Clin Oncol 22: 3284-3292, 2004.

15. Verwaal VJ, van Ruth S, de Bree E, et al. Randomized trial of cytoreduction and hyperthermic intraperitoneal chemotherapy versus systemic chemotherapy and palliative surgery in patients with peritoneal carcinomatosis of colorectal cancer. J Clin Oncol 21: 3737-3743, 2003.

16. Verwaal VJ, Bruin S, Boot H,et al. 8-year follow-up of randomized trial: cytoreduction and hyperthermic intraperitoneal chemotherapy versus systemic chemotherapy in patients with peritoneal carcinomatosis of colorectal cancer. Ann Surg Oncol 15: 2426-2432, 2008.

17. Garrett CR, George B, Viswanathan C, et al. Survival benefit associated with surgical oophorectomy in patients with colorectal cancer metastatic to the ovary. Clin Colorectal Cancer 11: 191-194, 2012.

18. http://www.nccn.org/professionals/physician_gls/pdf/colon. pdf (Access date: 01.27.2016).

19. Abu-Rustum NR, Chi DS, Wiatrowska BA, et al. The accuracy of frozen-section diagnosis in metastatic breast and colorectal carcinoma to the adnexa. Gynecol Oncol 73: 102-105, 1999.

20. Moore RG, Chung M, Granai CO, et al. Incidence of metastasis to the ovaries from nongenital tract primary tumors. Gynecol Oncol 93: 87-91, 2004.

21. Ojo J, De Silva S, Han E, et al. Krukenberg tumors from colorectal cancer: presentation, treatment and outcomes. Am Surg 77: 1381-1385, 2011.

22. Fujiwara $A$, Noura $S$, Ohue $M$, et al. Significance of the resection of ovarian metastasis from colorectal cancers. J Surg Oncol 102: 582-587, 2010.

23. Sugarbaker $\mathrm{PH}$. Surgical management of peritoneal carcinosis: diagnosis, prevention and treatment. Langenbecks Arch Chir Suppl Kongressbd 373: 189-196, 1988.

24. O'Dwyer S, Verwaal VJ, Sugarbaker PH. Evolution of Treatments for Peritoneal Metastases From Colorectal Cancer. J Clin Oncol 33: 2122-2123, 2015.

25. Goere D, Malka D, Tzanis D, et al. Is there a possibility of a cure in patients with colorectal peritoneal carcinomatosis amenable to complete cytoreductive surgery and intraperitoneal chemotherapy? Ann Surg 257: 1065-1071, 2013.
26. Verwaal VJ, van Tinteren H, Ruth SV, Zoetmulder FA. Toxicity of cytoreductive surgery and hyperthermic intra-peritoneal chemotherapy. J Surg Oncol 85: 61-67, 2004.

27. ICARuS Post-operative Intraperitoneal Chemotherapy (EPIC) and Hyperthermic Intraperitoneal Chemotherapy (HIPEC) After Optimal Cytoreductive Surgery (CRS) for Neoplasms of the Appendix, Colon or Rectum With Isolated Peritoneal Metastasis (ICARuS). https://clinicaltrials.gov/ct2/show/ NCT01815359.) Access date: 02.17.2016.

28. Debulking and Chemotherapy With or Without Intraperitoneal Chemotherapy to Treat Peritoneal Carcinomatosis. https:// clinicaltrials.gov/ct2/show/NCT00052962.) Access date: 02.17.2016.

29. Miller BE, Pittman B, Wan JY, Fleming M. Colon cancer with metastasis to the ovary at time of initial diagnosis. Gynecol Oncol 66: 368-371, 1997.

30. McCormick CC, Giuntoli RL, 2nd, Gardner GJ, et al. The role of cytoreductive surgery for colon cancer metastatic to the ovary. Gynecol Oncol 105: 791-795, 2007.

31. Kuijpers AM, Mehta AM, Aalbers AG, et al. Treatment of ovarian metastases of colorectal and appendiceal carcinoma in the era of cytoreductive surgery and hyperthermic intraperitoneal chemotherapy. Eur J Surg Oncol 40: 937-942, 2014.

32. Glehen O, Cotte E, Schreiber V, et al. Intraperitoneal chemohyperthermia and attempted cytoreductive surgery in patients with peritoneal carcinomatosis of colorectal origin. $\mathrm{Br} \mathrm{J}$ Surg 91: 747-754, 2004.

\section{Correspondence}

Dr. Zafer ARIK

Zekai Tahir Burak Kadin Sagligi Hastanesi

Tibbi Onkoloji Bölümü

06100, Sihhiye,

Ankara-TURKEY

Tel: (+90-312) 3065634

Fax: (+90-312) 3112485

e-mail: zaferarik@yahoo.com 